\title{
Staphylococcal infection and the limbus: study of the cell-mediated immune response
}

\author{
LINDA FICKER, DAVID SEAL, PETER WRIGHT \\ London
}

\begin{abstract}
Summary
The relationship between enhanced cell-mediated immunity (CMI) to staphylococcal antigens, expressed as delayed hypersensitivity (DH), and the development of catarrhal infiltrates at the limbus in the rabbit has been explored by others. This DH is required for infiltrates to develop in the rabbit cornea when it is exposed to conjunctival inoculation with live Staphylococcus aureus cells. Similar investigations have not been pursued in the human, although $S t$. aureus has been isolated from lids of patients with sterile marginal ulcers. We have tested 69 patients with blepharitis, eleven with and 58 without associated symptomatic marginal keratitis, for DH to killed whole cells of St. aureus and St. epidermidis and protein A; quantitative cultures have also been collected from lids and conjunctivae. Preliminary findings show that nine out of 11 patients with symptomatic marginal keratitis, requiring treatment with steroids, have enhanced DH to $S t$. aureus cell wall antigens. We suggest the hypothesis that this type of marginal keratitis in the human is the result of enhanced CMI at the limbus to $S t$. aureus cell wall antigens.
\end{abstract}

In 1946 Thygeson recorded the isolation of $S t$. aureus from the lids of 133 of 156 patients with catarrhal ulcers associated with chronic catarrhal conjunctivitis. ${ }^{1}$ Hogan et al. noted that marginal corneal infiltrates and ulcerations occasionally occurred during the course of lid infections when lid cultures usually grew $S t$. aureus, but cultures of the ulcers were sterile. ${ }^{2}$ They noted that single or multiple rounded or crescentic lesions developed in the peripheral corneal stroma separated from the limbus by a narrow rim of clear cornea. At times the multiple lesions extended to become a confluent partial ring infitrate, $1-2 \mathrm{~mm}$ wide and rarely deeper than the mid-stroma. They found recurrences and ulceration to be common with vascularisation occurring from the limbus. A non-infective 'hypersensitivity' aetiol- ogy was suggested based on rabbit experiments.

Marginal ulcers and phlyctenulae usually respond to topical steroid. ${ }^{2}$ While treatment alleviates symptoms, it is not curative and patients continue with recurrent marginal ulcers over many years. It is interesting that marginal ulcers and blepharitis may be asymmetrical or even unilateral.

In rabbit experiments Hogan et al. obtained no pathological effect by repeated topical installations of staphylococcal antigen or toxin in non-immunised rabbits. Injection of a challenging dose of staphylococcal antigen (cell wall/toxic filtrate) or toxoid into the central corneal stroma of rabbits, previously immunised subcutaneously with staphylococcal cell wall antigen or pure toxoid, did pro- 
duce corneal rings; staphylococcal cell wall antigen was twice as likely to produce this effect as toxoid. This has been explored further by Mondino and Kowalski ${ }^{3}$ to produce phlyctenules and catarrhal infiltrates, and Mondino et al. ${ }^{4}$ to produce a blepharitis model. On each occasion, prior immunisation of the rabbit was required with whole cells, or cell wall extracts, to give the rabbit a delayed hypersensitivity $(\mathrm{DH})$ response. This was followed by repeated exposure $(\times 6 /$ day for 5 weeks) of the eye to live St. aureus cells. The role of St. epidermidis is less well understood although DH can be induced to the organism in rabbit skin. ${ }^{5}$

This study was set up to determine whether the immunological findings in the rabbit, as discussed above, truly relate to the human disease. We have assessed whether recurrent marginal ulceration at the limbus is related to enhanced CMI to St. aureus cell wall antigens.

\section{Patient Studies and Methods}

We have investigated 69 patients with a clinical diagnosis of blepharitis of whom 11 had symptomatic marginal keratitis requiring treatment with steroids. We have tested their response to killed St. aureus and St. epidermidis and protein $\mathrm{A}$, using skin tests which were read after 15 minutes and 48 hours. We cultured lashes, lid margins and conjunctivae by a quantitative soluble swab method. ${ }^{6}$ All patients underwent slit-lamp examination and symptoms and signs were recorded.

Suspensions of St. aureus (NCTC 6571) and St. epidermidis (NCTC 7292) were prepared from heat-killed cultures and diluted to $5 \times 10^{8}$ cells $/ \mathrm{ml}$ in saline preserved with phenol (Bencard Ltd, Great West Road, Brentford, Middlesex TW8 9BD). Protein A was freshly prepared and diluted to 50 nanograms $/ \mathrm{ml}$ from purified freeze-dried protein A (Pharmacia Fine Chemicals Ltd). Each was injected intradermally; $0.1 \mathrm{ml}$ of the staphylococcal suspensions and $0.05 \mathrm{ml}$ of the protein A preparation. A control injection of $0.1 \mathrm{ml}$ saline preserved with phenol was also given intradermally. Early wheal and flare was read at 15 minutes while swelling and central induration was read at 48 hours.

\section{Results}

We found that 2.5 nanograms of protein $\mathrm{A}$ injected intradermally gave a wheal and flare response at 15 minutes in all patients but swelling and induration at 48 hours varied from nil to a swelling $100 \mathrm{~mm} \times 50 \mathrm{~mm}$. Patients were divided into three groups of 'normal' (0-20 mm), moderate $(21-60 \mathrm{~mm})$ and enhanced (greater than $60 \mathrm{~mm}$ ) reaction (DH) to this protein (Table).

Patients could be divided into two groups on the basis of induration at 48 hours to whole killed cells of St. aureus. Forty-one patients gave induration of $5 \mathrm{~mm}$ or greater (mean 7.2) and 28 had induration of $4 \mathrm{~mm}$ or less (mean 0.9). For patients with enhanced DH to $S t$. aureus cell walls, 51 per cent of reactions to protein A exceeded $60 \mathrm{~mm}$ and 27 per cent ranged between 21 and $60 \mathrm{~mm}$. For patients without $\mathrm{DH}, 72$ per cent gave reactions of 0-20 $\mathrm{mm}$ and 17 per cent gave a reaction of $21-60 \mathrm{~mm}$. The response to St. epidermidis had been minimal ( $<2 \mathrm{~mm})$ in 62 patients, but reached $4-5 \mathrm{~mm}$ in 7 patients, including two with marginal keratitis and enhanced $\mathrm{DH}$ to St. aureus.

Eight of 11 patients (average age 37 years) with symptomatic marginal keratitis, requiring treatment with steroids, were found in the

Table. Swelling reaction at 48 hours to intradermal injection of staphylococcal protein $A$ in 69 patients with blepharitis

\begin{tabular}{llll}
\hline & \multicolumn{3}{c}{ Number of patients in three response groups } \\
\cline { 2 - 4 } & $0-20 \mathrm{~mm}$ & $21-60 \mathrm{~mm}$ & $>60 \mathrm{~mm}$ \\
\hline All' blepharitis patients $(n=69)$ & 30 & 15 & 24 \\
& mean 5.3 & mean 40.5 & mean 79 \\
Subgroup with marginal keratitis $(n=11)$ & SD 5.8 & SD 9.3 & SD 20.7 \\
Marginal keratitis patients as $\%$ of total $(n=69)$ & 2 & 1 & 8 \\
\hline
\end{tabular}


group that gave an enhanced (greater than $60 \mathrm{~mm}) \mathrm{DH}$ effect to protein A (Table). Of the three patients without enhancement to protein $\mathrm{A}$, one in the $(0-20 \mathrm{~mm})$ group reacted with an enhanced response of $10 \mathrm{~mm}$ to whole killed cells of St. aureus. Three of 11 patients suffered from atopy, including the two who lacked an enhanced $\mathrm{DH}$ effect $(0-20 \mathrm{~mm})$ to protein A. Although atopic individuals can develop moderately enhanced DH $(21-60 \mathrm{~mm})$ to protein A without suffering from active staphylococcal infection, this effect has not been relevant with our patients.

St. aureus was only isolated from the lids of one of the patients with marginal keratitis, who had enhanced DH to St. aureus; this occurred on two occasions, four months apart, when the lids were 'scrubbed' with swabs soaked in tryptic digest broth which were then directly plated onto agar, but was not isolated by our soluble swab method. This lid 'scrubbing' method failed, however, to reveal St. aureus in the other 10 patients with marginal keratitis but mostly on only one occasion. Five of the 11 patients were receiving antibacterial therapy at the time of our examination, and none had acute ulceration.

\section{Discussion}

The cell wall of St. aureus contains peptidoglycan, teichoic acid and protein A while the cell wall of St. epidermidis lacks the protein A component. Protein A has been characterised, ${ }^{7,8}$ in particular it binds to the $\mathrm{Fc}$ part of the antibody molecule, forming nonspecific immune complexes, as well as acting as an antigen to which DH may be manifest as a CMI response. Protein $\mathrm{A}$ also binds to $\mathrm{Fc}$ receptors of $\mathrm{IgE}$ bound in turn to mast cells, liberating histamine and forming a wheal at 15 minutes (type I response). White and Noble have challenged 16 normal volunteers (aged 20-45 years) and 14 atopic individuals (aged 18-53 years) with 5.0 nanograms intradermal protein A (also from Pharmacia). For normals they recorded a mean zone of erythema at 48 hours of $2.4 \mathrm{~mm}$, with standard deviation (SD) of 2.6 and for atopes of $8.4 \mathrm{~mm}$ (SD 23.6); they recorded much larger indurated erythema at 24 hours of $33.5 \mathrm{~mm}$ (SD 22.2) and $17.0 \mathrm{~mm} \quad$ (SD 17.9) respectively. ${ }^{8}$
There is considerable evidence from experimental work in animals that the inflammatory reaction to cell walls of $S t$. aureus, and possibly $S t$. epidermidis, depends on previous and repeated exposure with the development of CMI to staphylococcal antigens expressed as DH. ${ }^{3-5.9 .10}$ Immunisation does not evoke this response at all sites, in particular excluding the anterior chamber. ${ }^{11}$ When evoked in the rabbit, the DH response gives rise to a marked inflammatory reaction to a small number of staphylococcal cells that would otherwise cause no effect; if the cells are given by the IV route this response can be fatal. ${ }^{5}$ It appears that the human likewise develops DH to $S t$. aureus but that this is not normally 'enhanced'. ${ }^{7.8 .12,13}$

Desensitisation of enhanced DH to $S t$. aureus has been attempted in both animals and man. Rabbits have been effectively desensitised using culture filtrates administered IV, but these are too toxic for humans. ${ }^{5}$ Killed cell vaccines, containing large numbers of organisms and given subcutaneously, fell into disrepute because some patients developed exacerbation of their infection with new abscesses, although occasional 'cures' occurred. This probably happened because the dose and route used resulted in enhancement of the $\mathrm{DH}$ response instead of its suppression. Repeated injection of staphylococcal phage lysate, given as $0.1 \mathrm{ml}$ intradermal injections, has been shown in the human to suppress DH to St. aureus. ${ }^{12}$ It may act by stimulating the development of $\mathrm{IgG}$ blocking antibodies, hence suppressing staphylococcal antigen expression.

The question arises whether recurrent marginal keratitis and ulceration are the result of a DH response at the limbus to St. aureus on the lids, in patients who have developed systemically enhanced DH to $S t$. aureus from previous infections, possibly due to a subtle PMN or macrophage defect. Our preliminary findings of enhanced DH to St. aureus antigens in nine of eleven patients with blepharitis and a history of marginal keratitis, support this hypothesis. Our results, however, only indicate the immune status of the patient as we failed to isolate $S t$. aureus on ten out of eleven occasions. This situation arose as we studied patients who were already receiving 
antibacterial and steroid therapy and who were not suffering from acute ulceration. Similar enhanced $\mathrm{DH}$ to protein $\mathrm{A}$ has been demonstrated by White and Noble in patients with psoriasis, ${ }^{8}$ an unrelated condition, so that detailed cellular immunology of the reactivity of our patients' $T$ lymphocytes is required to further establish the pathogenesis of this type of marginal keratitis.

\section{References}

${ }^{1}$ Thygeson P: Marginal corneal infiltrates and ulcers. Tr Am Acad Ophthalmol 1946, 51: 198-209.

${ }^{2}$ Hogan MJ, Diaz-Bonnet V, Okumoto M, Kimura SJ: Experimental staphylococcic keratitis. Invest Ophthalmol 1962, 1: 267-72.

${ }^{3}$ Mondino BJ and Kowalski RP: Phylctenulae and catarrhal infiltrates-occurrence in rabbits immunised with staphylococcal cell walls. Arch Ophthalmol 1982, 100: 1968-71.

${ }^{4}$ Mondino BJ, Caster AI, Dethleefs B: A rabbit model of staphylococcal blepharitis. Arch Ophthalmol 1987, 105: 409-12.

${ }^{5}$ Boe J: Investigations on the importance of bacterial allergy for the development of cutaneous infections due to staphylococci. Acta Dermato-Venereol 1945/46, 26: 111-36.
${ }^{6}$ Badiani D, Bron A, Elkington A, Lea SH et al.: Use of a novel transport method for the quantification of the normal flora of the external eye. Microb Ecol Health Dis 1988, 1: 57-9.

${ }^{7}$ Langone JJ: Protein A of Staphylococcus aureus and related immunoglobulin receptors produced by Streptococci and pneumococci. in Easman CSF, Adlam C eds. Staphylococci and staphylococcal infections. London: Academic Press, 1983, 157252.

${ }^{8}$ White MI and Noble WC: The cutaneous reaction to staphylococcal protein A in normal subjects and patients with atopic dermatitis or psoriasis. $\mathrm{Br} J$ Dermatol 1985, 113: 179-83.

${ }^{9}$ Panton PN and Valentine FCO: Staphylococcal infection and reinfection. Br J Exp Pathol 1929, 10: $257-62$.

${ }^{10}$ Johanovsky J: Role of hypersensitivity in experimental staphylococcal infection. Nature 1958, 182: 1454.

11 Johnson JE, Cluff LE, Goshi K: Studies on the pathogenesis of staphylococcal infection. $J$ Exp Med 1960, 113: 235-47.

${ }^{12}$ Mudd S, Taubler J, Baker AG: Delayed-type hypersensitivity to Staphylococcus aureus in human subjects. J Reticuloendothel Soc 1970, 8: 493-8.

${ }^{13}$ Russell MR, Crowder JG, White A: Human reactions to staphylococcal antigens. J Immunol 1967, 99: $269-75$. 